\title{
$C_{0} \mathbf{I} \cdot \mathbf{R}^{\circ} \mathbf{P} \cdot \mathrm{E}^{\prime} \mathrm{E}$
}

Centre Interuniversitaire sur le Risque, les Politiques Économiques et l'Emploi

\section{Privatization and Globalization: an Empirical Analysis}

\author{
Narjess Boubakri \\ Jean-Claude Cosset \\ Nassima Debab \\ Pascale Valéry
}

Septembre/September 2011

\footnotetext{
Boubakri: American University of Sharjah and CIRPÉE

Cosset: HEC Montréal and CIRPÉE

Debab: HEC Montréal and CIRPÉE

Valéry: HEC Montréal and CIRPÉE. Corresponding author: Pascale Valéry, HEC Montréal, Department of Finance, 3000 chemin de la Côte-Sainte-Catherine, Montréal, Québec, Canada H3T 2A7. Tél.: 1 514 340-7004; Fax: 1514 340-5632 Webpage: http://neumann.hec.ca/pages/pascale.valery/pascalevalery.htm

pascale.valery@hec.ca
}

We are grateful to Robert Chirinko, Jonathan Chiu, Olfa Maalaoui Chun, Jens Hagendorff, Steven Jordan, Inmoo Lee, Miguel Molico, Hajime Tomura, Francisco Rivadeneyra, Bhavik Parikh and to Finance seminar participants at the Graduate School of Finance, Korea Advanced Institute of Science and Technology (KAIST) for helpful comments as well as seminar participants at the Bank of Canada. This work has been presented at the 2011 MFA meetings and at the 2011 INFINITI Conference. We are grateful to Hyacinthe Somé for valuable research assistance. This work is supported by the Social Sciences and Humanities Research Council of Canada (SSHRC). 


\begin{abstract}
:
This paper examines the link between globalization measured by foreign direct investment (FDI) and foreign portfolio investment (FPI) and privatization of state-owned enterprises in a multi-country sample that focuses on developing countries. We hypothesize that privatization has an effect on FDI/FPI as the process of fostering private sector participation was often accompanied by liberalization reforms, and by allocations of substantial shares in newly privatized firms to foreign investors. Similarly, we expect FDI/FPI to foster privatization efforts as new capital inflows, technology and managerial skills that accompany FDI/FPI make the environment more prone to competition, providing governments with incentives to privatize inefficient firms that need to be turned around. This relation is assessed in two ways, first in a dynamic panel using a generalized method of moments approach, and second through panel causality tests.
\end{abstract}

Keywords: Privatization, foreign direct investment, foreign portfolio investment, dynamic panel GMM, panel causality tests

JEL Classification: G28, G34, O16 


\section{PRIVATIZATION AND GLOBALIZATION: AN EMPIRICAL ANALYSIS}

\section{$1 \quad$ Introduction}

Twenty-five years ago, many countries around the world launched economic reform programs to foster private sector development, mainly through the privatization of state-owned entities. The primary aim of these programs is to decrease government control in the economy, and to transfer the ownership of former state-owned enterprises (SOEs) from the state to private investors. As pointed out by Shleifer (1998), the inefficiency of SOEs that was largely blamed on the political objectives pursued by the bureaucrats who managed these firms, was the principal impetus for privatization. Other objectives of the reform included boosting local stock markets and improving the country's institutional environment. The reform then spread worldwide as economic globalization and markets integration increased. In a world with more intensive international competition, more liberalized stock markets worldwide and less restrictive trade barriers across countries, the need to develop and foster private sector activities became a necessity, leading to an international shift of economic policies towards private sector development.

The pace of the privatization process has been both sustained and global, still today, after more than two decades elapsed from its start (World Bank, 2006). When countries promote economic policies that favour private ownership, they simultaneously attract the attention of foreign investors, either of multinational corporations, in the form of foreign direct investment (FDI) or of individual and institutional investors in the form of foreign portfolio investment (FPI $)^{3}$. In the case of developing countries, the World Bank (2003) notes, for instance, that FDI has become the largest and most resilient form of capital flows. Some studies sustain that privatization was instrumental in the FDI growth observed worldwide. For example, Baer (1994) notes that privatization had an impact on foreign investments in many Latin American countries, where the increase of foreign capital has been accompanied by a decline in the extent of involvement of the state in the economy. Likewise, The World Bank in its 2008 Global Development Finance notes that the surge in FDI inflows to Europe and Central Asia in 2007 was associated with privatization programs as was the case for the large volume of FDI inflows to Latin America in the late 1990s. Other arguments in the literature hold that privatization, often accompanied with a combination of other measures that aim to improve the investment climate, lift barriers to trade and provide a better and more effective institutional environment, contributed to the rise in FDI flows over the last twenty years.

The past twenty-five years have also been marked by an impressive growth in the stock market capitalization of most countries. Boutchkova and Megginson (2000), Perotti and van Oijen (2001) and Bortolotti et al. (2007) show that share issue privatizations had a major impact on the growth and liquidity of non-U.S. stock

\footnotetext{
${ }^{3}$ Portfolio investors are mainly profit-motivated, whereas direct investors seek to exert control over assets.
} 
markets and on the participation of individual and institutional investors therein, particularly through the allocations to foreigners in initial public offerings of privatized firms. However, it could also be argued that economic reforms, like trade and financial liberalization, as well as overall institutional reforms including reduction of bureaucracy, control of corruption and improvement of investors' rights protection, would spur globalization through FDI and FPI, independently of the launching of privatization programs.

Like privatization, FDI and FPI, two proxies for globalization, have witnessed a significant and steady progress around the world. The rising trend in FDI around the globe is analyzed in several World Bank reports. Particularly, the World Bank (2002) reports that FDI has positively responded to government implementations of privatization programs, and notes that seven of the ten largest FDI recipients received more than \$US1 billion from foreign investors to participate in the privatization transactions that were conducted in 1999 . The intensity of the privatization program seems to be strengthened by massive increases in FDI flows which continued to increase throughout the 2000s. FDI brings about many benefits ranging from fund-raising, new technologies, improvements in human capital, new managerial skills and improved corporate governance. It comes thus as no surprise that several privatization transactions on the stock market involved the sale of a tranche directly aimed at foreign investors. Likewise, The World Bank reports that the net portfolio equity inflows to developing countries increased dramatically over the recent period: from \$11 billion in 1999 to \$145.1 billion in 2007 (Global Development Finance, 2008). The joint foreign investment inflows (direct investment and portfolio investment) to developing countries totaled $\$ 536$ billion in 2008, down 19 percent from the $\$ 664$ billion recorded in 2007 but still almost 14 percent higher than the inflow recorded in 2006 (Global Development Finance, 2010). This suggests that developing countries still draw a major source of funds from foreign investors.

The objective of this paper is to examine the link between privatization and globalization, measured by FDI and FPI, for developing countries. We focus on developing economies including Brazil, Russia, India and China (BRIC) due to their importance in attracting foreign investors. Also, developing countries display more homogeneous levels of economic development as well as institutional and legal environments which substantially differ from those of developed countries. More specifically, we examine in this paper the potential bi-directional causality between privatization and globalization. In particular, we investigate whether privatization is a determinant of globalization, and whether globalization enhanced and contributed to the sustainability of the privatization process. To our knowledge, this is the first multinational empirical study of the potential link between privatization and globalization. The use of international data from developing economies allows us to provide new evidence and to draw several novel insights and policy implications.

Besides, it is important to keep in mind that we are interested in the sum of inflows and outflows FDI/PFI, which varies with the level of economic development. For instance, while large-scale privatization programs in developed countries are aimed at reducing their budget deficit, and spreading popular capitalism, developing 
countries launch these programs to attract foreign investment, and financial help from world development agencies. Developing countries thus mostly face foreign inflows. Although we are interested in globalization in general, namely inflows and outflows, foreign capital flows are less likely to go in both directions for developing countries.

The empirical analysis of the role of privatization in determining foreign direct investment (FDI) and foreign portfolio investment (FPI), and the role of FDI and FPI in affecting privatization is important for several reasons: First, FDI and FPI flows are an engine for future economic growth and institutional development. Examining the role of specific economic reforms as a determinant of FDI and FPI flows is thus important for policy purposes. Second, assessing the link between a redistributive (often opposed) policy such as privatization, and an equally controversial phenomenon, such as FDI and FPI, is important on theoretical grounds. Several governments met strong opposition as they launched privatization programs, further fuelled by the announcement that the potential buyers were foreign investors. Previous firm-level studies have examined the link between foreign participation and postprivatization firm performance (e.g., D’Souza and Megginson, 1999; Harper, 2002; Boubakri, Cosset, Guedhami, 2005a, Boubakri, Cosset, Guedhami, 2005b). On the macro-economic level however, whether globalization and privatization are mutual determinants remains an issue to explore.

Why, beyond the anecdotal evidence described above, should privatization and globalization be related? Several potential channels can be put forward. First, privatization usually improves the investment climate thus making investment more attractive for investors, domestic and foreign alike, and contributes to enhance the growth and development process. For instance, a recent study by Boubakri, Cosset and Smaoui (2009) shows that privatization contributes to the improvement in the overall institutional quality of the country -i.e. its rule of law and law enforcement mechanisms. Similarly, Mishkin (2009) argues that globalization is a powerful driver of institutional reforms, particularly in developing countries. Second, while the effect of privatization on growth remains yet to be assessed, available evidence from countries that pursued privatization does reveal significant positive outcomes, especially at the firm level (see Megginson and Netter, 2001, for an extensive review of this literature). Finally, within the context of private risk taking, privatization should reinforce the globalization phenomenon as privatization, through share issues, has a positive impact on stock market developments and drains FDI and FPI flows. Parallel to this effect, we also argue that more financially open economies are more likely to privatize extensively. These mechanisms of transmission between globalization (FDI/FPI) and privatization have been unexplored to date. Although privatization and globalization are two concomitant, reinforcing mechanisms, they have always been treated in two separate strands of the literature: The privatization literature has focused on the outcome of the reform on several aspects, such as the performance of newly privatized firms, corporate governance, legal institutions, stock market liquidity, etc. The FDI literature has instead focused on its impact on economic growth and welfare, and social inequality (e.g., Noorbakhsch, Paloni 
and Youssef, 2001; Aitken, Harrison and Lipsey, 2001; Khawar, 2005). The FPI literature has also mostly focused on the impact of foreign equity flows on the benefits and extent of international portfolio diversification, local stock prices and stock market volatility (e.g., French and Poterba, 1990; Cho, Kho and Stulz, 1999; Froot, O’Connell and Seasholes, 2001; Karolyi and Stulz, 2003).

Using a sample of 56 developing countries, over the period 1984 to 2006 that ends up just before the financial crisis, we run the following: First, we implement a generalized method of moments (GMM) approach in a dynamic panel context to estimate the parameters. This approach allows us to control for the problems of joint endogeneity of the independent variables, reverse causality and simultaneity, and country heterogeneity, i.e., unobserved country-specific fixed effects (see Arellano and Bond (1991) and Arellano and Bover (1995)) that produce inconsistent estimators. In addition, this estimation approach makes use of information contained both in levels and differences to yield efficient estimators of the parameters. Second, we conduct formal causality tests in both directions, from privatization to globalization, and from globalization to privatization, in a closely-related panel specification as proposed by Holtz-Eakin, Newey and Rosen (1988), using a GMM estimator based on a two-stage least squares (2SLS) first-step estimator. Finally, we conduct tests of weak instruments as recommended by Stock, Wright and Yogo (2002), Stock and Yogo (2005) to check whether the causality tests do not suffer from size distortions due to weak instruments, for the results to be reliable. Thus, not only the instruments employed in the instrumental variable estimation technique have to be valid (i.e. not correlated with the disturbance term), but also relevant (sufficiently correlated with the endogeneous variable to be replaced) for the results to be meaningful (unbiased estimators and correctly sized tests).

In so doing, we find support for our principal conjecture: Indeed, after controlling for several factors shown to determine privatization, we find that globalization has a positive effect on privatization proceeds and privatization method. We also find that privatization proceeds and the privatization method do influence the extent of FDI in a country, suggesting that FDI flows and privatization are interrelated. However, the results do not support the hypothesis that privatization impacts FPI. Our results suggest that privatization can be instrumental in attracting FDI, which can contribute to domestic economic growth: privatization through share issues fosters stock market development, and financial development is known to exert a major influence on economic growth (Levine, 2004; Bekaert, Harvey and Lundblad, 2005). By the same token, privatization constitutes a credible signal of less policy risk for foreign investors, and contributes to attract more FDI. When performing panel causality tests, we do find evidence of a bi-directional causation between both phenomena confirming our hypothesis that globalization (through FDI) fosters privatization and vice-versa. However, when globalization is measured by FPI, we are unable to reject the null of no causality between both phenomena. More specifically, the dynamics and channels of transmission between the privatization method and FPI are more difficult to identify. 
As robustness checks, we control for business cycle influences, political orientation of the government, investors' rights protection, and international accounting standards. Our results remain robust to these checks.

The rest of the paper is organized as follows: Section 2 presents some stylized facts on FDI/FPI and privatization. Section 3 discusses the empirical approach and the variables. Section 4 presents the sample, some descriptive statistics and discusses the empirical results along with robustness checks. Section 5 concludes.

\section{Stylized facts and testable hypotheses}

The literature on privatization suggests that domestic economic conditions influence the decision of governments to privatize, and the way they structure privatization. For instance, governments facing high budget deficits, or fiscal crises are more likely to undertake privatization (Ramamurti, 1992). Also, Megginson, Nash, Netter and Poulsen (2004) argue that countries with higher deficits are more likely to privatize state-owned assets by share issued privatizations (SIPs) than by private sales. However, Boubakri, Cosset and Guedhami (2005a) show that whether privatization is implemented by SIPs or private sales in developing countries, foreign direct investment is omnipresent (foreign investors participated in 86\% of privatization transactions between 1980 and 1999 in developing countries). The literature (e.g., Bortolotti, Fantini and Siniscalco, 2003) has identified other determinants of the decision to privatize: for example, the role of the political orientation of the government conditions the decision to privatize as right-wing governments who wish to promote "popular capitalism" are more likely to privatize than left-wing governments. In addition, a financially-distressed government faced with a high level of public debt is more likely to privatize in order to meet its financial obligations, and countries with a lower protection of investors' rights and a weak legal environment are less likely to privatize.

FDI and FPI flows can be additional potential determinants of privatization. Since FDI enhances the competitiveness of the domestic economy, contributes to more skilled labour, helps to import new technology, it should result in a positive externality on the environment. As a consequence, governments will have more incentives to privatize if the economy is more open to foreign investment. Hence, we expect that more foreign direct investment in the country will contribute to enhance privatization efforts by local governments. FDI and mainly FPI flows will also create new inflows for governments willing to privatize through SIPs. This discussion leads to the following hypotheses:

H1A: Globalization (that is, FDI and FPI) has a positive impact on privatization proceeds, everything else being equal.

H1B: Globalization (that is, FDI and FPI) has a positive impact on the proportion of share issue privatizations in the total number of privatizations transactions, everything else being equal. 
The literature also identifies several determinants of FDI and FPI. Li and Resnick (2003, p.203) argue that with respect to foreign direct investment: "While increasing levels of democracy help to produce better judicial systems and rule of law, these higher levels of democracy also drive foreign investors away by imposing constraints on foreign capital and the host government." Law and order means a more predictable regulatory environment, less prone to unexpected policy reversals, and is therefore consistent with a more transparent policymaking process.

Financial liberalization is also a determinant of FDI and FPI. Financial liberalization allows foreign investors to invest, without particular restrictions, in the domestic market, and allows domestic investors to trade freely on international financial markets. The recent liberalization reforms in emerging markets resulted in an increased presence of foreign investors that typically bring in addition to their funds, stricter disclosure rules, more accounting transparency, new management and governance skills (see Bekaert, Harvey and Lundblad, 2005). Market-related variables such as GDP (market size), GDP per capita and GDP growth also represent traditional FDI determinants (see, for example, Schneider and Frey, 1985; Tsai, 1994) as well as trade liberalization which measures the extent of openness of the country to foreign trade which is shown to be positively related to FDI flows.

The literature on cross-border equity transactions focuses on the role of two key determinants: information frictions and the quality of host-country institutions. Portes and Rey (2005) find that, in addition to market size, efficiency of the transactions technology, distance, a proxy for information frictions, has a negative effect on the level of cross-border equity flows. The authors suggest different proxies for the degree of information asymmetry between domestic and foreign investors including telephone call traffic, the degree of overlap in trading hours, multinational bank branches to account for information transmission, and insider trading. In a more recent study, Daude and Fratzscher (2008) show that cross-border portfolio investment is sensitive to different institutional indicators like the degree of information disclosure in local credit markets regulations and accounting standards in the host country. The authors also document that portfolio investment reacts to the risk of expropriation and repudiation costs, confirming Albuquerque's (2003) hypothesis that portfolio investment is easier to expropriate than other types of investment. Finally, stock market openness and development appear to be positively related to cross-border portfolio investment.

In addition to these classic determinants of FDI and FPI, we consider the potential impact of privatization. We argue that if the governments' objective is to attract FDI or FPI flows, a credible environment of contract enforcement and transparency needs to be put in place. Privatization can provide the government with such a credible signal (Perotti, 1995), particularly in the case of share issue privatization (by opposition to private sales). Perotti's model suggests that gradual sales, with an immediate transfer of control, signal that the government is ready to assume residual policy risk and that it does not intend to alter the value of newly privatized firms through 
a future change in economic policies. Therefore, share issue privatizations should signal commitment to investors whose increased confidence is likely to attract more FDI and FPI flows. This discussion leads to the following hypotheses:

H2A: Privatization proceeds have a positive impact on globalization (that is, FDI and FPI), everything else being equal.

H2B: The proportion of share issue privatizations in the total number of privatization transactions has a positive impact on globalization (that is, FDI and FPI), everything else being equal.

\section{Methodology}

The methodology is threefold. First, we identify (possible) reinforcing links between both phenomena, privatization and globalization, using a GMM-system estimation technique in a dynamic panel setting as recommended by Arellano and Bond (1991), and Arellano and Bover (1995), to exploit information on both dimensions, namely cross-sectional (across countries) and time-series. Second, we conduct formal causality tests in both directions, from privatization to globalization, and from globalization to privatization, in a closely-related panel specification as proposed by Holtz-Eakin, Newey and Rosen (1988), using a GMM estimator based on a two-stage least squares (2SLS) first-step estimator. Finally, we conduct tests of weak instruments as recommended by Stock, Wright and Yogo (2002), Stock and Yogo (2005) to check whether the causality tests do not suffer from size distortions due to weak instruments, to ensure that the results are reliable.

\subsection{Dynamic panel GMM-system estimation technique ${ }^{4}$}

This approach allows us to control for the problems of joint endogeneity of the independent variables, reverse causality and simultaneity, and country heterogeneity, i.e., unobserved country-specific effects (see Arellano and Bond (1991) and Arellano and Bover (1995)). Specifically, we are concerned with finding empirical evidence that would support the hypothesis of the two-way relation running from FDI/FPI flows to privatization and vice-versa. Therefore, we make use of an empirical strategy which does account for a simultaneity bias arising from a possible reverse causality between both phenomena in a dynamic panel data set. In other words, we resort to the dynamic panel-data estimation, two-step system GMM, following Blundell and Bond (1998), that addresses these endogeneity problems by exploiting all the information contained in the data set to provide valid instruments. Following Windmeijer (2005), we also implement the finite-sample corrected standard errors for the efficient two-step GMM estimator throughout the procedure. Without this correction, the two-step GMM standard errors are known to be severely biased downwards leading thereby to mechanically low p-values.

\footnotetext{
${ }^{4}$ Dynamic panel GMM-system estimation is performed using Xtabond2 with the STATA software.
} 
Since the validity of GMM estimates crucially hinges on the exogeneity assumption for the instruments, we perform the Hansen $\mathbf{J}$ over-identification test to check for the joint validity of the moment conditions. In addition, we test for autocorrelation by applying the Arellano and Bond test to the residual in differences. This test should find spurious autocorrelation of order 1 and no sign of autocorrelation of order 2 in the residual first differences. Furthermore, to identify the impact of privatization on FDI/FPI flows and reciprocally, it is necessary to control for some effects already identified in the literature. The design for our panel data analysis will incorporate the influence of the other factors as follows.

For the privatization equation, we consider:

$$
\begin{aligned}
& P R I V_{i t}=\rho P R I V_{i t-1}+\phi_{1} F D I_{i t}+\gamma C L V_{i t}+\mu_{i}+\varepsilon_{i t} \\
& P R I V_{i t}=\rho P R I V_{i t-1}+\phi_{1} F P I_{i t}+\gamma C L V_{i t}+\mu_{i}+\varepsilon_{i t}
\end{aligned}
$$

The foreign direct investment (FDI) flows equation is as follows:

$$
F D I_{i t}=\rho F D I_{i t-1}+\phi_{0} P R I V_{i t}+\gamma C L V_{i t}+\mu_{i}+\varepsilon_{i t}
$$

The foreign portfolio investment (FPI) flows equation is as follows:

$$
F P I_{i t}=\rho F P I_{i t-1}+\phi_{0} P R I V_{i t}+\gamma C L V_{i t}+\mu_{i}+\varepsilon_{i t}
$$

$i$ denotes the country, $i=1, \ldots, N$, and $t$ the time index, $t=1, \ldots, T$, for yearly observations; $\mu_{i}$ will account for the unobserved country-specific effect. $C L V_{i t}$ represents country-level variables that control for the potential determinants of either privatization, or globalization (FDI/FPI). Table 1 provides the list of the country-level variables we consider.

\subsection{Panel causality tests}

We adopt the following dynamic specification for the panel data causality tests (Holtz-Eakin, Newey and Rosen, 1988), and thus investigate the potential causal relations between both phenomena, i.e. from privatization to globalization (FDI/FPI) and vice versa:

$$
y_{i t}=\alpha+\rho_{1} y_{i t-1}+\rho_{2} y_{i t-2}+\beta_{1} x_{i t-1}+\beta_{2} x_{i t-2}+\mathrm{B} \tilde{x}_{i t}+\mu_{i}+\varepsilon_{i t} \text {. }
$$

To remove the country-specific fixed effects $\mu_{i}$, the model is differentiated. In doing so, we introduce a simultaneity problem because the error term becomes correlated with the regressor $y_{i t-1}-y_{i t-2}$. Indeed, $y_{i t-1}$ in $y_{i t-1}-y_{i t-2}$ is by construction correlated with $\varepsilon_{i t}-\varepsilon_{i t-1}$ in the specification in differences:

$y_{i t}-y_{i t-1}=\rho_{1}\left(y_{i t-1}-y_{i t-2}\right)+\rho_{2}\left(y_{i t-2}-y_{i t-3}\right)+\beta_{1}\left(x_{i t-1}-x_{i t-2}\right)+\beta_{2}\left(x_{i t-2}-x_{i t-3}\right)+B\left(\tilde{x}_{i t}-\tilde{x}_{i t-1}\right)+\left(\varepsilon_{i t}-\varepsilon_{i t-1}\right)$.

Therefore, an instrumental variable estimation based on GMM is conducted to tackle this simultaneity/endogeneity issue. Note that the three-stage least-squares estimator is a GMM estimator that uses a slightly different weighting matrix than the optimal GMM, but uses the same orthogonality conditions. The 
instrumental variables used in the estimation increase with $t$, as more information is included when $t$ increases. Using the GMM estimator with the weighting matrix evaluated at the 2SLS estimator, we are able to perform panel causality tests as recommended by Holtz-Eakin, Newey and Rosen (1988). Also, the test statistic revolves around the sum of squared residuals, and therefore is easy to implement. Indeed, the statistic to test the null hypothesis that $x$ does not cause $y$, involves linear restrictions on the estimated parameters. Specifically, the null hypothesis of no causality running from $x$ to $y$ corresponds to a test of the joint hypothesis: $\beta_{i}=\cdots=\beta_{i}=\cdots=\beta_{N}=0$, that sets to zero the coefficients on the causal variable across units in the panel. We use an extension of White's (1980) heteroskedasticity consistent covariance matrix estimator to account for possible heteroskedasticity in the data. Furthermore, when the sample size is limited, the use of the full set of moment conditions can lead to poor finite-sample performance for the GMM estimator (Andersen and Sorensen, 1996; Ahn and Schmidt, 1995); that is the reason why the 3SLS-GMM estimator used here only involves the information contained in the equation in differences. Indeed, Andersen and Sorensen (1996), Bowsher (2002) and Roodman (2007) document that instrument proliferation can distort the size of the test: when the instrument count is too large relative to the time series dimension, the test never rejects the null hypothesis. Thus, many instruments tend to produce perfect $\mathrm{p}$ values of 1.00 for the Hansen $\mathbf{J}$ statistic. Hence, to address our concern for undersized tests and produce reliable results, we purposely choose a moderate number of instruments for the causality tests to produce reliable results. Further, we tackle potential weak instrument problems. As pointed out by Stock, Wright and Yogo (2002), Stock and Yogo (2005), unfortunate consequences of weak instruments are twofold: first they may cause instrumental variable estimators to be biased; second hypothesis tests of parameters estimated by instrumental variable estimators may suffer from severe size distortions that produce misleading results. After checking for the validity of the instruments, we test the relevance of the instruments for the causal relations to hold.

\subsection{Variables}

Foreign direct investment (FDI) is measured as the ratio of FDI inflows and FDI outflows to GDP; likewise, foreign portfolio investment (FPI) is measured for each country, as the sum, in absolute value, of equity securities assets and equity securities liabilities standardized by GDP 5 .

The control variables for the globalization (FDI/FPI) equations are the following:

\footnotetext{
${ }^{5}$ Eiteman, Stonehill and Moffett (2007, chap. 3, p.74-75): "Whenever $10 \%$ or more of the voting shares in a U.S. company are held by foreign investors, the investment is classified as a foreign direct investment. In contrast, when the investment does not reach the $10 \%$ ownership threshold of direct investment, it is classified as a portfolio investment. If a U.S. resident purchases shares in a Japanese firm but it does not reach the 10\% threshold, it is classified as a portfolio investment (i.e. an outflow of capital)", or equity securities asset. Conversely, equity is treated as a liability of the issuing institutional unit. "In principle, world portfolio investment assets should equal world portfolio investment liabilities" (IMF, News Brief 2000).
} 
1) Trade openness, used by Eichengreen and Leblang (2008), is measured as the logarithm of the sum of exports and imports of goods and services. The more a country is open and integrated into the world economy, the greater the likelihood for the country to attract FDI.

2) Distance is the logarithm of the total physical distance, using latitude and longitude coordinates, separating the capital city of each country $(\mathrm{i}=1, \ldots, \mathrm{N})$ to the capital city $\mathrm{j}$ of the 15 countries with the largest market capitalization in 2005 , i.e.,

$$
d_{i}=\sum_{j=1, \ldots, 15} d_{i j}
$$

Distance is a proxy for informational asymmetries, (Portes and Rey, 2005, Daude and Fratzscher, 2008). A negative sign is expected on both measures FDI/FPI.

3) Market capitalization is measured as a share of GDP. Market capitalization represents financial markets' size, (Portes and Rey, 2005). We expect financial development to attract more FDI.

4) The index of Law and Order, used by La Porta, Lopez-de-Silanes, Shleifer and Vishny (1998), is measured on a scale from 0 to 6 (the best outcome). The index of Law and Order is an assessment of the strength and impartiality of the legal system, and of popular observance of the law. Thus, a country can enjoy a high rating in terms of its judicial system, but a low rating if it suffers from a high crime rate, and if the law is routinely ignored without effective sanction. Thus, the higher the law and order in the country, the more predictable regulatory environment, the less prone to unexpected reversals, the more the government commits itself to protect investors and hence the greater the likelihood to attract FDI.

5) The investment profile measures the risk to investment, i.e. the risk of expropriation, repudiation costs. Albuquerque (2003) argues that FPI is easier to expropriate than other types of investment. The assigned risk rating is the sum of three subcomponents, i.e., contract viability and expropriation risk, profits repatriation and payment delays, (a score of $4=$ very low risk and a score of $0=$ very high risk). The higher the index of investment profile, the better the investment environment, hence a positive sign is expected on FPI.

We consider two different measures of privatization used in previous studies (e.g., Bortolotti, Fantini and Siniscalco, 2003; Boubakri, Cosset, and Smaoui, 2009): (1) the ratio of privatization proceeds to GDP as a measure of the volume of privatization (PRIVPROC); (2) the number of share issue privatization (SIP) to the total number of privatization transactions (Public Offers and Private Sales), (PRIVMETH) captures the method of privatization and the willingness of the government to use the stock market as a source of financing. The control variables for the privatization equation are the following:

(1) A measure of credit rating provided by Institutional Investor. Bankers are asked to grade each of the countries on a scale of zero to 100 , with 100 representing those with the least chance of default. Financial distressed governments are more likely to privatize, (Bortolotti, Fantini and Siniscalco, 2003). 
(2) A dummy variable for the legal environment since, in contrast to common law countries, civil law countries are not strong advocates of investors' protection, and therefore less prone to privatize, (Bortolotti, Fantini and Siniscalco, 2003).

(3) A measure of political constraints constructed by Henisz (2000) that measures the feasability of a change in policy given the structure of a nation's political institutions (number of veto points) and the preferences of the actors that inhabit them (the partisan alignment of various veto points and the heterogeneity or homogeneity of the preferences within each branch). Possible scores range from zero (most hazardous) to one (most constrained).

(4) A dummy variable for the political orientation of the government since a right-wing government (outcome=1) is more likely to privatize than a left-wing government (outcome=0), (Bortolotti, Fantini and Siniscalco, 2003).

(5) An index of corruption within the political system (outcome $=6$ with very low risk), (outcome=0, with very high risk). Kaufmann and Siegelbaum (1997, p.419) analyzed corruption and privatization phenomena for transition economies finding that both phenomena tend to be positively correlated: "If you think privatization is corrupt, try without it." 6

\section{$4 \quad$ Empirical Results}

Our sample consists of 56 developing economies ${ }^{7}$, over the period 1984 to 2006 , with yearly observations. The sample ends up in 2006, so that the data is not contaminated by the financial crisis that started in summer 2007. The list and the definition of the variables as well as their data sources appear in Table 1.

Insert Table 1 here.

Table 2 reports descriptive statistics on the main variables, including deviations from normality such as asymmetries (skewness coefficients far from 0), and fat-tailed features (kurtosis coefficients far from 3). Although trade openness looks close to a normal variable once it has been transformed into logarithm, the normal distribution is strongly rejected from the data. All other variables strongly reject the null hypothesis of normality.

\footnotetext{
${ }^{6}$ Anonymous official, in response to the Ukrainian parliament's decision to halt the privatization program on the grounds of possible corrupt methods (1994)

7 The sample of emerging economies consists of Albania, Algeria, Argentina, Armenia, Bangladesh, Bosnia and Herzegovina, Brazil, Bulgaria, Cameroon, Chile, China, Colombia, Cote d'Ivoire, Croatia, Czech Republic, Ecuador, Egypt, Estonia, Georgia, Ghana, Hungary, India, Indonesia, Jamaica, Jordan, Kazakhstan, Kenya, Latvia, Lithuania, Malaysia, Mexico, Moldova, Morocco, Nigeria, Pakistan, Peru, Philippines, Poland, Republic of Macadonia, Romania, Russia, Slovak Republic, Slovenia, South Korea, Sri Lanka, Thailand, Trinidad and Tobago, Tunisia, Turkey, Uganda, Ukraine, Uzbekistan, Venezual, Zambia, Zimbabwe.
} 
Insert Table 2 here.

\subsection{Correlations}

Table 3 shows the pairwise correlations between the main variables. The correlation between both measures of privatization and FDI is positive and significant at the 5\% significance level, suggesting a potential relation between privatization and globalization. The correlation coefficients between both measures of privatization and FPI are not significant suggesting an unclear relation between both phenomena. As for the control variables, trade openness is positively correlated with both measures of globalization at the 5\% significance level, as predicted by the literature. Indeed, the less barriers to trade, the more direct and portfolio investors are attracted into the country. Also, the extent of privatization in terms of revenues is more likely in trade liberalized economies. Further, the higher the sovereign credit ratings, the less likely the default for the governments, the more confident foreign portfolio investors, the more foreign portfolio investment will flow into the economies. In the same vein, the more developed the financial markets, the more likely foreign portfolio investors will be attracted to developing economies. Furthermore, the strong correlation between the stock market capitalization and FPI, as twice as much as FDI, supports the claim that financial development matters more to foreign portfolio investors than to foreign direct investors who look for majority ownership stakes to benefit from an ownership concentration (see LLSV, 1998, 1999). In view of the positive and significant correlation between investment profile and FPI, foreign portfolio investors are more likely to invest in a friendly investment environment while foreign direct investors seem less sensitive to the investment profile. Indeed, Albuquerque (2003) argues that portfolio investors are easier to expropriate than other types of investors. Likewise, privatizing governments are more likely to drain revenues in a friendlier investment environment. The positive and significant correlation between the corruption index and FPI, meaning that the less risk of corruption, the more foreign portfolio investors will invest, supports the claim that portfolio investments are more sensitive to institutional indicators such as the degree of corruption than FDI (see Daude and Fratzscher, 2008). Interestingly, the better the institutional indicators i.e., investment profile and corruption index, the higher are the sovereign credit ratings. These univariate relations, although informative, do not exploit all cross-sectional information contained in the data. Hence a multivariate analysis is required.

Insert Table 3 here.

\subsection{Impact of globalization on privatization}

We observe from Table 4 that globalization tends to boost privatization revenues, when globalization is measured by FDI, bringing strong evidence in favour of our hypothesis (H1A). Further, the higher the sovereign credit 
rating, the less likely the default, the less the government needs to privatize in order to drain revenues. In addition, we make use of the political constraints index built by Henisz (2000, p.5) as a measure of the feasibility of change in policy that gauge the "ability of political institutions to provide a credible commitment to private property rights". Thus, Henisz (2000, p.5) develops a measure of institutional commitment that uses "the number of independent veto points over policy outcomes and the distribution of preferences of the actors that inhabit them". Hence, the higher the political constraints index designed by Henisz (2000, p.3), the more likely the government is willing to "credibly commit not to interfere with private property rights", the less uncertainty for investors, the more privatization proceeds will flow into the economy. As Perotti (1995) has shown, populist governments tend to avoid gradual sales and tend to interfere, even after the sale, through policy changes (regulation, taxation, changes in regulated rates,...). The author argues that (1995, p.848), "gradual sales (with immediate transfer of control) imply that the government is willing to bear residual risk, a signal that it does not intend to redistribute value through a future shift in policy." Further, the less the risk of corruption, the more privatization proceeds are drained into the economies, as less corrupt governments tend to maximize revenues instead of selling at discounted prices to favoured bidders. Regarding the method of privatization, the more foreign direct investors are involved, the more share issue privatizations are issued on the stock market, which sustains our hypothesis (H1B). Interestingly, the control variables impact the method of privatization differently: this time, the higher the sovereign credit ratings, the less likely the default, the more share issue privatizations take place on the stock market. In contrast to the privatization proceeds, the less the risk of corruption, the less SIPs are issued on the stock market; in other words, when the degree of corruption is high, privatizing on the stock market instead of using direct sales helps to regulate the economic environment. Further, legal institutions do matter in privatizing countries, but the negative effect from the legal origin on privatization proceeds is controversial, as revenues from privatization should be more important in English common law countries than in French civil law countries (see Bortolotti, Fantini and Siniscalco, 2003). However, the negative sign is mainly due to the importance of civil law countries in our sample, as all the countries with high average privatization revenues have a civil law legal system. Finally, the results do not support the hypothesis that FPI affects privatization; although a relation has been pinned down for different specifications, it is nevertheless unstable and very sensitive to the sample size. Regarding the Arellano and Bond test for the autocorrelation in the residuals, the outputs in Table 4 provide no evidence that the model is misspecified at the $5 \%$ conventional level for the privatization proceeds, while this is unclear for the method of privatization.

Insert Table 4 here. 


\subsection{Impact of privatization on globalization}

As shown in Table 5, we find strong evidence in favour of hypothesis $(\mathrm{H} 2 \mathrm{~A})$ that privatization proceeds positively affect FDI. Similarly, the data do support hypothesis (H2B) that share issue privatization on the stock market helps to deepen globalization, when globalization is measured by FDI. Meanwhile, FPI flows are very sensitive to the risks of expropriation and to profits repatriation that determine a good-quality environment for foreign investors, as pointed out by Daude and Fratzscher (2008). Indeed, foreign portfolio investors are more sensitive to institutional indicators than FDI, as they are easier to expropriate than direct investors. To overcome the lower protection offered to investor, foreign investors typically look for majority ownership stakes which are more likely to be obtained through private sales transactions rather than on the stock market. Majority stakes allow foreign investors to benefit from an ownership concentration that has been shown to be inversely related to investor protection (see LLSV, 1998, 1999). Moreover, Distance that proxies for information asymmetries (Portes and Rey, 2005; Daude and Fratzscher, 2008) displays the negative expected sign, meaning that the more distant the economies, the most likely information asymmetries will prevail. Trade openness and financial development spur foreign investment into the economy, as "global trade as a share of GDP rose from $7.7 \%$ to $19.5 \%$, and the share of countries open to international capital flows rose from 25\% to 38\%" between 1975 and 2002 (see Eichengreen and Leblang, 2008, p. 290). Overall, the most important lesson we can draw from Table 5 is the striking impact from both measures of privatization on FDI. The effect is inconclusive for FPI.

Insert Table 5 here.

\subsection{Panel causality tests}

In the previous section, we have examined the sign and the statistical significance of the coefficients. A formal causality test is required, however, to assess the existence and the direction of the causal relation between privatization and globalization. First, we test, in Table 6, the null hypothesis that privatization proceeds do not cause FDI, after controlling for its well-known determinants (trade openness and financial development, the quality of institutions, and information frictions). We ask ourselves whether privatization proceeds carry relevant extra information that is not already contained in the past observations of FDI. In other words, regressing FDI on its own past and other explanatory variables is not sufficient to capture all the variations in the law of motion of FDI. The causality tests are thus conducted using a 3SLS estimator with GMM-style instruments to overcome endogeneity/simultaneity problems. Besides, the causal effects are measured in a dynamic relation including two lags of the endogenous variable. Further, the reverse causality running from globalization to privatization is investigated, when testing whether FDI does not cause privatization. In view of the small p-values shown in panel A (Table 6), or the large values of the likelihood ratio (LR) statistic, we strongly reject the null hypothesis that 
FDI does not cause privatization at all conventional significance levels, and vice-versa. Indeed, the critical points given by a chi-squared distribution with 24 degrees of freedom (number of restrictions tested) at the 5\%, 1\% significance levels are equal to 36.41 and 42.98 , respectively, which are much smaller than the LR reported values in panel A (Table 6). However, when globalization is measured by FPI as shown in panel B (Table 6), we cannot reject the null hypothesis of no-causality between privatization and FPI and vice-versa. As Table 5 already suggested, the results do not support our conjecture that privatization proceeds contribute to explain the law of motion of FPI. In other words, when globalization is measured by FPI, privatization proceeds do not bring extra information beyond what is already contained in the past dynamic of FPI. The reverse causality running from FPI to privatization proceeds is not supported by the data. In sum, we provide statistical evidence in favour of a bidirectional causality running from privatization to globalization that holds only for FDI. A technical appendix is available upon request from the authors that describes the details of the procedure for those interested in replicating the results.

\section{Insert Table 6, panels A and B here.}

\subsection{Tests for weak instruments}

To detect whether or not the causality tests reported above could be influenced by weak instruments problems, we further perform tests of weak instruments. A glance at the first-stage regression statistics enables us to detect the presence of weak instruments, as instrumental variable estimators display less bias when instruments are strongly correlated with the endogeneous variable. Just looking at the $R^{2}$ and adjusted $R^{2}$ can be misleading, as those statistics can be large even though instruments are weak. The partial $R^{2}$ is robust to correlation between the endogeneous variable and the included exogeneous variables in the regression. Based on those statistics, we observe that the first sixth lags of PRIV have a better explanatory power than the first sixth lags of FDI and FPI, whose $R^{2}$ are lower ${ }^{8}$. Similarly, the $\mathrm{F}$ statistics for the joint significance of the coefficients on the additional instruments are strongly significant. All F statistics are larger than $10^{9}$, as recommended by Stock, Wright and Yogo (2002) for inference based on the 2SLS estimator to be reliable when there is one endogeneous regressor. The minimum eigenvalue statistic, recommended by Cragg and Donald (1993), provides a further test of weak instruments, whose values are exactly equal to the F statistics. Using the first characterization of weak instruments proposed by Stock and Yogo (2005), whatever relative bias (2SLS relative to OLS) we are willing to tolerate, the

\footnotetext{
${ }^{8}$ The R-squares, adjusted R-squares and partial R-squares are respectively $0,4083,0,3963$ and 0,4041 for the first sixth lags of PRIV, (0.1474, 0.1359, 0.1114 for the first sixth lags of FDI, respectively; $0.1454,0.1265,0.1445$ for the first sixth lags of FPI).

9 The first-stage 2SLS regression $F$ statistics are respectively $F(6,539)=60.92$ for PRIV, $F(6,818)=17.10$ for FDI and $\mathrm{F}(6,496)=13.96$ for FPI.
} 
F statistic displayed by PRIV exceeds the critical values ${ }^{10}$. In contrast, for FDI and FPI we need to increase the 2SLS relative bias to $10 \%$ to be able to reject the null of weak instruments. Regarding the second characterization proposed by Stock and Yogo (2005), who show that hypothesis tests of parameters estimated by instrumental variable estimators may suffer from severe size distortions, again PRIV displays a F statistic that is higher than all critical values corresponding to the $5 \%$ nominal size of the Wald test ${ }^{11}$. In contrast for FDI (resp. for FPI), if we are not willing to tolerate an actual rejection rate larger than $15 \%$ for a $5 \%$ nominal size test (20\% for FPI), then the set of instruments is weak. However, using the LIML estimator instead allows us to reject the null hypothesis of weak instruments for FDI and FPI as both F statistics exceed $4.45^{12}$. We may therefore conclude that the causality tests based on those instruments do not suffer from size distortions due to weak instruments that would produce misleading results.

\subsection{Robustness checks}

To verify that our results are robust, we conduct a series of controls related to alternative data frequency, and additional control variables such as the political orientation, the anti-self-dealing index and international accounting standards.

\subsubsection{Data Averaged Over Three-Year Periods}

As foreign direct investment, foreign portfolio investment and privatization proceeds are all sensitive to the business cycle, we consider three-year averaged data instead of annual data to abstract from business cycle influences. Still, FDI positively affects privatization proceeds at the $1 \%$ significance, but not the method of privatization. Again, we observe that privatization proceeds positively and significantly impact FDI, supporting once again hypothesis H2A after controlling for business cycle influences. Regarding the privatization method, the results obtained on averaged data are not supportive of hypothesis H2B anymore. Most control variables remain significant and robust to business cycle influences. Due to space constraints, the results are not reported, but are available upon request.

\subsubsection{Additional Control Variables: the political orientation variable POLITO}

To test for the robustness of the results shown in Table 4, we substitute the political orientation variable POLITO to the political constraints variable Polcon. We can observe in Table 7 that FDI still boosts privatization proceeds,

\footnotetext{
${ }^{10}$ The 2 SLS relative bias critical value for one endogenous regressor is 19.28 at $5 \%$ and 11.12 at $10 \%$.

${ }^{11}$ The critical values corresponding to the 2SLS size of a nominal 5\% Wald test is equal to 29.18 for an actual rejection rate of $10 \%, 16.23$ for an actual rejection rate of $15 \%$ and to 11.72 for an actual rejection rate of $20 \%$.

${ }^{12}$ The critical values corresponding to the LIML size of a nominal 5\% Wald test is equal to 4.45 for an actual rejection rate of $10 \%$ and 3.34 for an actual rejection rate of $15 \%$.
} 
(but the effect is lost for the privatization method). Most control variables remain significant with the same sign. Interestingly, the political orientation variable POLITO is significant with the same sign as Polcon, which supports the claim that right-wing governments are more likely to privatize than left-wing governments, as pointed out by Bortolotti, Fantini and Siniscalco (2003). More specifically, right-wing governments, who are market-oriented, are more likely to drain revenues from privatization, as they are more concerned with maximizing sales revenues. Interestingly, FPI does contribute to privatization proceeds in this specification with an economically and statistically significant coefficient (at the $1 \%$ level). Also, FPI seems sensitive to control variables and to sample size.

Insert Table 7 here.

\subsubsection{Additional Control Variables: Anti-self-dealing index and International Accounting Standards}

We also test whether the results are robust to other control variables, including International Accounting Standards (IAS), that is a dummy variable that takes the value 1 for countries that comply with IAS, or declare intended, and 0 otherwise. In the FDI specification, the law and order variable is replaced with the International Accounting Standards variable, while the legal origin variable is replaced in the FPI specification. We find that the strong positive effects between privatization proceeds and FDI displayed in Tables 4 and 5 do survive (at the $1 \%$ significance level) while the weak effects between FDI and SIPs do vanish when introducing the IAS variable.

We also control for the anti-self dealing-index, whose index has been downloaded from Andrei Schleifer's webpage. The index, introduced by Djankov, La Porta, Lopez-de-Silanes, and Shleifer (2008), addresses the ways in which the law deals with corporate self-dealing in a theoretical way. The authors start with "a stylized selfdealing transaction, and then measure the hurdles that the controlling shareholder must jump" for his transaction to get through (Djankov, La Porta, Lopez-de-Silanes, and Shleifer, 2008, p. 432). "The higher the hurdles, the higher is the anti-self-dealing index", or the stronger is the minority shareholder's protection. As the index is not available in panel, we compute the median value over all countries and then construct a dummy variable which takes the value 1 for countries whose anti-self-dealing index is higher than the median and 0 otherwise. We then replace the legal system variable with the anti-self dealing dummy variable in the regressions. After controlling for investors' rights protection, the strong positive effects between privatization proceeds and FDI, shown in Tables 4 and 5, still remain (at the 1\% significance level). However, the significant effect of FDI on SIPs reported in Table 4 is not robust to the anti-self dealing index, since the coefficient is not significant anymore. Similarly, the significant effect from SIPs to FDI does not hold anymore when the legal origin variable is replaced with the anti-self dealing variable. Thus, the strong positive relations between FDI and privatization proceeds (at $1 \%$ significance levels) are robust to anti-self-dealing index while most of the control variables remain significant and robust to it. Although the anti-self dealing variable is not significant for FDI, it matters for FPI whose coefficient 
is significant; this emphasizes the importance of investors' rights protection for portfolio investors (see LLSV, 1998, 1999; Bortolotti, Fantini and Siniscalco, 2003; Albuquerque, 2003; Daude and Fratzscher, 2008). Due to space constraints, the results are not reported, but are available upon request.

\section{$5 \quad$ Concluding remarks}

In this paper, we examine the link between globalization (FDI/FPI) and privatization of state-owned enterprises in a multi-country sample that focuses on developing countries. We conjecture that privatization has an effect on globalization as the process of fostering private sector participation often involved the allocation of substantial shares to foreign investors in newly privatized firms. Similarly, we expect FDI /FPI to foster privatization efforts as new capital inflows, technology and managerial skills that accompany globalization make the economic environment more prone to competition, thus fostering GDP growth. We provide strong evidence of a bidirectional positive relation between privatization proceeds and FDI. Furthermore, although the link connecting FDI/FPI to the extent of share issue privatizations is more difficult to identify, we find a positive relation running from FDI to share issue privatizations, and vice-versa. In sum, by improving the investment climate, privatization helps to attract investors, domestic and foreign alike, and contributes to enhance the growth and development process.

A policy implication of our study is that privatization programs in an economic environment that is investment-friendly can draw foreign investors who will bring the capital flows, technology and managerial skills that are needed to turn around inefficient firms. As shown in this study, FDI flows have accompanied and responded positively to government privatization programs in developing countries. In addition, the intensity of privatization programs seems to have been strengthened by massive increases in FDI flows which continued to increase throughout the 2000s. It is thus no surprise that several privatization transactions on the stock market involved the sale of a tranche directly aimed at foreign investors. Both phenomena, the worldwide launching of privatization programs and FDI flows seem therefore to have a reinforcing dynamic in all settings. Regarding portfolio investment flows, the evidence of such a relationship is weaker: the formal causality test does not support the existence of a causal relation between FPI and privatization proceeds. To our knowledge, ours is the first multinational empirical study on the potential bi-directional relation between privatization and FDI/FPI flows. 
Table 1: Definitions, Proxies and Data sources

\begin{tabular}{|c|c|c|c|c|}
\hline Variable & Proxy & Label & Exp. sign & Source \\
\hline Foreign direct investment & Sum of inflows and outflows standardized by the GDP & FDI & + & IMF data base \\
\hline $\begin{array}{l}\text { Foreign portfolio } \\
\text { investment }\end{array}$ & $\begin{array}{l}\text { Sum in absolute value of equity securities assets } \\
\text { and equity securities liabilities standardized by the GDP }\end{array}$ & FPI & + & International Financial Statistics \\
\hline Method of Privatization & $\begin{array}{l}\text { Number of privatizations by share issues to the total } \\
\text { number of privatizations }\end{array}$ & PRIVMETH & + & $\begin{array}{l}\text { SDC Platinium, Thomson } \\
\text { Financial }\end{array}$ \\
\hline Trade openness & Log of the sum of imports and exports of good and services & TRADE & + & World Development Indicator \\
\hline Law and Order & $\begin{array}{l}\text { Assessment of the strength and impartiality of the legal system } \\
\text { and of popular observance of the law. }\end{array}$ & LO & + & International Country Risk Guide \\
\hline Market capitalization & Market capitalization as a share of GDP & Marketcap & + & World Development Indicators \\
\hline Distance & $\begin{array}{l}\text { Distance is the logarithm of the total physical distance, } \\
\text { using latitude and longitude coordinates between the home capital } \\
\text { city } \mathrm{i} \text { and the capital city } \mathrm{j} \text { of the } 15 \text { largest market } \\
\text { capitalization countries. }\end{array}$ & Distance & - & CIA: The World Factbook \\
\hline Investment profile & $\begin{array}{l}\text { Risk rating assigned to contract viability, } \\
\text { expropriation risk, profits repatriation and payment delays, } \\
\text { (a score of } 4=\text { very low risk and a score of } 0=\text { very high risk) }\end{array}$ & Invest_profile & + & International Country Risk Guide \\
\hline Sovereign credit ratings & $\begin{array}{l}\text { Bankers are asked to grade each of the countries on a scale of zero } \\
\text { to } 100 \text {, with } 100 \text { representing those with the least chance of default. }\end{array}$ & Credit ratings & + & Institutional Investor \\
\hline
\end{tabular}


Table 1: Definitions, Proxies and Data sources

\begin{tabular}{|c|c|c|c|c|}
\hline Variable & Proxy & Label & \begin{tabular}{|l|} 
Exp. \\
sign
\end{tabular} & Source \\
\hline Corruption & $\begin{array}{l}\text { Measure of excessive patronage, nepotism, job reservations, } \\
\text { secret party funding, (a score of } 6=\text { very low risk } \\
\text { and a score of } 0=\text { very high risk). }\end{array}$ & Corruption & + & International Country Risk Guide \\
\hline Legal Origin & $\begin{array}{l}\text { Dummy that is equal to one if the legal origin is common law, } \\
\text { and zero otherwise. }\end{array}$ & Legal & + & $\begin{array}{l}\text { La Porta, Lopez-de-Silanes, Shleifer } \\
\text { and Vishny (1998) }\end{array}$ \\
\hline $\begin{array}{l}\text { Political constraints } \\
\text { index }\end{array}$ & $\begin{array}{l}\text { The political constraints index measures the feasability of a change in } \\
\text { policy given the structure of a nation's political institutions } \\
\text { (number of veto points) and the preferences of the actors that inhabit them } \\
\text { (the partisan alignment of various veto points and the heterogeneity or } \\
\text { homogeneity of the preferences within each branch). Possible scores range } \\
\text { from zero (most hazardous) to one (most constrained). }\end{array}$ & Polcon & + & Henisz's webpage \\
\hline Political Orientation & 1 right-wing, 0 left-wing & POLITO & + & $\begin{array}{l}\text { Database on Political Institutions } \\
\text { (WORLD BANK) }\end{array}$ \\
\hline $\begin{array}{l}\text { Anti-self-dealing } \\
\text { dummy }\end{array}$ & $\begin{array}{l}\text { A dummy variable which takes the value } 1 \text { for countries whose anti-self- } \\
\text { dealing } \\
\text { index is higher than the median and } 0 \text { otherwise. The dummy variable is } \\
\text { constructed from the anti-self dealing index provided by Djankov et al (2008). }\end{array}$ & $\begin{array}{l}\text { Anti-self- } \\
\text { dealing }\end{array}$ & + & Andrei Shleifer's webpage \\
\hline IAS & $\begin{array}{l}\text { International Accounting Standards compliance: dummy }=1 \text { if the } \\
\text { country enacted or declared intended; dummy }=0 \text { if no compliance at all. }\end{array}$ & IAS & + & Financial Standards foundation \\
\hline
\end{tabular}


Table 2: Descriptive statistics

\begin{tabular}{|c|c|c|c|c|c|c|c|c|c|c|}
\hline Var & FDI & FPI & Privproc & Privmeth & Trade & Market cap & Invest_profile & Legal & Credit & Polcon \\
\hline Mean & 3.145 & .0053 & .4050 & .1166 & 4.134 & 30.761 & 5.549 & .1406 & 29.342 & .2807 \\
\hline Median & 1.800 & .0003 & 0 & 0 & 4.146 & 16.542 & 6 & 0 & 27.675 & .34 \\
\hline Std. error & 10.788 & .0139 & 1.232 & .2839 & .5338 & 44.372 & 3.217 & .3477 & 18.939 & .2154 \\
\hline Skewness & 26.323 & 5.499 & 5.648 & 2.532 & -.3557 & 4.042 & -.341 & 2.067 & .2239 & -.0999 \\
\hline Kurtosis & 813.727 & 44.284 & 43.125 & 7.916 & 3.044 & 28.317 & 2.383 & 5.274 & 2.286 & 1.615 \\
\hline $\begin{array}{l}\text { Test for } \\
\text { normality }\end{array}$ & Rejected & Rejected & Rejected & Rejected & Rejected & Rejected & Rejected & Rejected & Rejected & Rejected \\
\hline \# obser & 1307 & 1091 & 1360 & 678 & 1354 & 853 & 1472 & 1472 & 1472 & 1357 \\
\hline
\end{tabular}


Table 3: Correlation coefficients

\begin{tabular}{|c|c|c|c|c|c|c|c|c|c|c|c|c|}
\hline & FDI & FPI & Proc & Meth & Trade & Credit rat. & Legal & marketcap & Polcon & Invest & corr & distance \\
\hline FDI & 1.00 & & & & & & & & & & & \\
\hline FPI & $0.2635^{*}$ & 1.00 & & & & & & & & & & \\
\hline Proc & $0.0883^{*}$ & 0.0498 & 1.00 & & & & & & & & & \\
\hline Meth & $0.1571 *$ & 0.0590 & $-0.1280 *$ & 1.00 & & & & & & & & \\
\hline Trade & $0.1464 *$ & $0.1430 *$ & $0.1140 *$ & $0.0860 *$ & 1.00 & & & & & & & \\
\hline Credit rat. & 0.0149 & $0.2959 *$ & $0.0600 *$ & $0.1947^{*}$ & $0.1811 *$ & 1.00 & & & & & & \\
\hline Legal & $-0.0558 *$ & 0.0582 & $-0.0786^{*}$ & -0.0172 & -0.0270 & $0.1735^{*}$ & 1.00 & & & & & \\
\hline marketcap & $0.1371 *$ & $0.2667 *$ & -0.0588 & $0.1496 *$ & $0.1867^{*}$ & $0.3416 *$ & $0.3257^{*}$ & 1.00 & & & & \\
\hline Polcon & $0.2004 *$ & $0.2314^{*}$ & $0.1666^{*}$ & 0.0124 & $0.1392 *$ & $0.2942 *$ & 0.0371 & $0.0788^{*}$ & 1.00 & & & \\
\hline Invest & 0.0217 & $0.1976 *$ & $0.1008 *$ & $0.1365^{*}$ & $0.0917^{*}$ & $0.6535^{*}$ & $0.0993^{*}$ & $0.1546 *$ & $0.2208 *$ & 1.00 & & \\
\hline corr & $-0.0704 *$ & $0.0664 *$ & 0.0510 & $-0.1033^{*}$ & $-0.1220 *$ & $0.4120 *$ & $0.1522^{*}$ & $0.1224 *$ & $0.0925 *$ & $0.5641 *$ & 1.00 & \\
\hline distance & -0.0286 & $-0.0866^{*}$ & $-0.0627^{*}$ & 0.0085 & $-0.3354 *$ & $0.0711 *$ & $0.1354^{*}$ & $0.2006 *$ & $0.0839 *$ & $0.2511 *$ & $0.3101 *$ & 1.00 \\
\hline
\end{tabular}

Significance at the $5 \%$ level is indicated with a *. 
Table 4: Impact of globalization on privatization

PRIVPROC $_{i t}=\rho_{1}$ PRIVPROC $_{i-1}+\phi_{1} F$ II $_{i i}+\gamma C L V_{i t}+\mu_{i}+\varepsilon_{i t}$

PRIVMETH $_{i t}=\rho_{1}$ PRIVMETH $_{i-1}+\phi_{1} F P I_{i i}+\gamma C L V_{i t}+\mu_{i}+\varepsilon_{i t}$

\begin{tabular}{|c|c|c|c|c|c|}
\hline & PRIVPROC & PRIVMETH & & PRIVPROC & PRIVMETH \\
\hline & FDI & & & FPI & \\
\hline Lag 1 & $.1186451 *$ & .0588262 & & $.0933022 * *$ & .0359217 \\
\hline FDI & $.1402149 * * *$ & $.023519 * * *$ & FPI & -.4264508 & .0117124 \\
\hline Credit_ratings & $-.007795 * * *$ & $.0036005^{* * *}$ & & -.0016702 & $.0058788^{* * *}$ \\
\hline Legal & -.0735445 & .0040136 & & $-.3236766 * * *$ & -.0400572 \\
\hline Polcon & $.4678844 * * *$ & -.0523354 & & $1.067725^{* * *}$ & -.0319919 \\
\hline Corruption & $.0501093 *$ & $-.0406985^{* * *}$ & & $.0755613^{* *}$ & $-.0411898 * * *$ \\
\hline $\begin{array}{l}\text { Hansen J } \\
\text { test(pvalue) }\end{array}$ & 1.00 & 1.00 & & 1.00 & 1.00 \\
\hline $\begin{array}{l}\text { A-B test for } \\
\text { AR(1) (pvalue) }\end{array}$ & 0.004 & 0.006 & & 0.004 & 0.020 \\
\hline $\begin{array}{l}A-B \text { test for } \\
A R(2) \text { (pvalue) }\end{array}$ & 0.258 & 0.035 & & 0.209 & 0.032 \\
\hline \# Observations & 1237 & 491 & & 1026 & 415 \\
\hline
\end{tabular}

***, **, * refer to significance at the $1 \%, 5 \%$, and 10\%, respectively. PRIVPROC and PRIVMETH are two different measures of privatization, while FDI and FPI are two different measures of globalization. The Arellano and Bond test applied to the residual in differences should find spurious autocorrelation of order 1 and no sign of autocorrelation of order 2 . The Hansen $\mathbf{J}$ statistic tests for the validity of the overidentifying restrictions. 
Table 5: Impact of privatization on globalization

\begin{tabular}{|c|c|c|c|c|c|}
\hline & FDI & FPI & & FDI & FPI \\
\hline & PRIVPROC & & & PRIVMETH & \\
\hline Lag 1 & $.7035885^{* * *}$ & $.7883243^{* * *}$ & & $.5704496 * * *$ & $.7397486 * * *$ \\
\hline PRIVPROC & $.4651913^{* * *}$ & -.0000716 & PRIVMETH & $1.202336 * *$ & .0004282 \\
\hline Invest_profile & & $.0001309 *$ & & & $.0001739 * *$ \\
\hline Legal & & -.0005763 & & & .0002044 \\
\hline Distance & $-.195725 * * *$ & & & $-.280203 * * *$ & \\
\hline Marketcap & .0048564 & $.0000373 *$ & & .0028938 & .0000351 \\
\hline Trade open. & $.6919463 * * *$ & & & $1.062549 * * *$ & \\
\hline Law_order & .0392895 & & & .106531 & \\
\hline $\begin{array}{l}\text { Hansen J } \\
\text { test(pvalue) }\end{array}$ & 1.00 & 1.00 & & 1.00 & 1.00 \\
\hline $\begin{array}{l}\text { A-B test for } \\
A R(1) \text { (pvalue) }\end{array}$ & 0.000 & 0.009 & & 0.003 & 0.043 \\
\hline $\begin{array}{l}A-B \text { test for } \\
A R(2) \text { (pvalue) }\end{array}$ & 0.184 & 0.046 & & 0.209 & 0.176 \\
\hline \# Observations & 838 & 680 & & 564 & 455 \\
\hline
\end{tabular}

$* * *, * *, *$ refer to significance at the $1 \%, 5 \%$, and $10 \%$, respectively. PRIVPROC and PRIVMETH are two different measures of privatization, while FDI and FPI are two different measures of globalization. The Arellano and Bond test applied to the residual in differences should find spurious autocorrelation of order 1 and no sign of autocorrelation of order 2 . The Hansen $\mathbf{J}$ statistic tests for the validity of the overidentifying restrictions. The control variables for the FDI regression include distance, market cap, trade, and law and order, while they include invest-profile, corruption, distance and market cap for FPI regression. 
Table 6: Panel Causality tests with 3SLS-GMM style instruments

\section{Panel A: Bi-directional causation between privatization and FDI}

\begin{tabular}{lll}
\hline & $P R I V \rightarrow F D I$ & $F D I \rightarrow P R I V$ \\
\hline LR stat & $\mathbf{3 4 1 . 6 6 2 7}$ & $\mathbf{8 8 . 8 6 3 8}$ \\
pvalue & $\mathbf{0 . 0 0 0}$ & $\mathbf{0 . 0 0 0}$ \\
\# Observations & 289 & 289 \\
Control var. included & & \\
Trade open. & YES & \\
Distance & YES & \\
Law and order & YES & \\
Market cap & YES & \\
Credit ratings & & YES \\
Legal & & YES \\
Polcon & & YES \\
Corruption & & YES \\
\hline
\end{tabular}

Panel B: Failure to reject the noncausality between privatization and FPI

\begin{tabular}{lll}
\hline & $P R I V \rightarrow F P I$ & $F P I \rightarrow P R I V$ \\
\hline LR stat & $\mathbf{0 . 0 1 0 0 0 7}$ & $\mathbf{3 . 2 1 1 9}$ \\
pvalue & $\mathbf{1 . 0 0 0}$ & $\mathbf{0 . 9 9 9 9 9 9 8}$ \\
\# Observations & 289 & 289 \\
Control var. included & & \\
Invest_profile & YES & \\
Distance & YES & \\
Law and order & YES & \\
Market cap & YES & \\
Credit ratings & & YES \\
Legal & & YES \\
Polcon & & YES \\
Corruption & & YES \\
\hline
\end{tabular}

To test the null hypothesis of no causality running from $x$ to $y$, we use the following specification on differentiated variables to remove the country-specific fixed effects $\mu_{i}$ :

$Y_{t}=\alpha+\rho_{1} Y_{t-1}+\rho_{2} Y_{t-2}+\beta_{1} X_{t-1}+\beta_{2} X_{t-2}+\mathrm{B} \tilde{X}_{t}+\mu_{i}+\varepsilon_{t}$,

and four control variables in each specification. First, we test the null that the privatization proceeds measured by $x=P R I V$ do not cause $y=F D I(F P I)$, where the control variables for FDI(FPI) are distance, trade openness, law and order and market capitalization (investment profile, distance, law and order and market capitalization, respectively). Then, we test for the reverse causality, i.e. from $y=F D I$ to $x=P R I V$, where the control variables for the privatization proceeds are the sovereign credit ratings, the legal origin, the political constraints index and the corruption index. The estimation methodology used to perform the tests is 3SLS with GMM-style instrumental variables as recommended in Holtz-Eakin, Newey and Rosen (1988), using the optimal GMM weighting matrix. We use the likelihood ratio test statistic, which is the difference between the restricted sum of squared residuals and the unrestricted sum of squared residuals. The likelihood ratio test statistic has a chi-square distribution as $\mathrm{N}$ grows, with the degree of freedom given by the number of restrictions. 
Table 7 (Robustness Tests: Polito)

PRIVPROC $_{i t}=\rho_{\mathrm{i}}$ PRIVPROC $_{i-1}+\phi_{1} F D I_{i t}+\gamma C L V_{i t}+\mu_{i}+\varepsilon_{i t}$

PRIVMETH $_{i t}=\rho_{1}$ PRIVMETH $_{i-1}+\phi_{1} F P I_{i i}+\gamma C L V_{i t}+\mu_{i}+\varepsilon_{i t}$

\begin{tabular}{|c|c|c|c|c|c|}
\hline & PRIVPROC & PRIVMETH & & PRIVPROC & PRIVMETH \\
\hline & FDI & & & FPI & \\
\hline Lag 1 & 1436752 & .0074389 & & $.1441655^{* *}$ & .022292 \\
\hline FDI & $.1516313^{* * *}$ & .0055222 & FPI & $5.981634^{* * *}$ & -.1317364 \\
\hline Credit_ratings & $-.0073781 * *$ & $.0041045 * * *$ & & $3.69 \mathrm{e}-06$ & $.0047896 * * *$ \\
\hline Legal & .0068317 & -.0257118 & & $-.3598651 * * *$ & -.0111009 \\
\hline Polito & $.2671076 * *$ & .0056314 & & $.2667068 * *$ & -0.000004 \\
\hline Corruption & .0352376 & $-.0370872^{* * *}$ & & $.0957248 * * *$ & $-.0381473 * * *$ \\
\hline $\begin{array}{l}\text { Hansen J } \\
\text { test(pvalue) }\end{array}$ & 1.00 & 1.00 & & 1.00 & 1.00 \\
\hline $\begin{array}{l}\text { A-B test for } \\
\text { AR(1) (pvalue) }\end{array}$ & 0.040 & 0.012 & & 0.035 & 0.020 \\
\hline $\begin{array}{l}\text { A-B test for } \\
\text { AR(2) (pvalue) }\end{array}$ & 0.481 & 0.163 & & 0.334 & 0.130 \\
\hline \# Observations & 779 & 315 & & 643 & 263 \\
\hline
\end{tabular}

$* * *, * *, *$ refer to significance at the $1 \%, 5 \%$, and $10 \%$, respectively. PRIVPROC and PRIVMETH are two different measures of privatization, while FDI and FPI are two different measures of globalization. The Arellano and Bond test applied to the residual in differences should find spurious autocorrelation of order 1 and no sign of autocorrelation of order 2. The Hansen J statistic tests for the validity of the overidentifying restrictions. 


\section{Bibliography}

Ahn, S. C. and Schmidt, P. (1995) "Efficient Estimation of Models for Dynamic Panel Data “, Journal of Econometrics, 68, 5-27.

Aitken, B., A. Harrison and Lipsey, R. (1996) "Wages and Foreign Ownership: A Comparative Study of Mexico, Venezuela, and the United States", Journal of International Economics, 42, 345-371.

Albuquerque, R., (2003) “The Composition of International Capital Flows: Risk Sharing through Foreign Direct Investment”, Journal of International Economics, 61, 353-383.

Andersen, T. G. and Sorensen, B. E. (1996) “GMM Estimation of a Stochastic Volatility Model: a Monte Carlo Study “, Journal of Business and Economic Statistics, 14, 328-352.

Arellano, M. and Bond S. (1991) "Some Tests of Specification for Panel Data: Monte Carlo Evidence and an Application to Employment Equations”, Review of Economic Studies, 58, 277-297.

Arellano, M. and Bover, O. (1995) "Another Look at the Instrumental Variable Estimation of Error Component Models", Journal of Econometrics, 68, 29-51.

Bekaert, G., Harvey, C. R., and Lundblad, C. (2005) “ Does Financial Liberalization Spur Growth ?” , Journal of Financial Economics, 77, 3-55.

Blundell, R. and Bond, S (1998) "Initial Conditions and Moment Restrictions in Dynamic Panel Data Models", Journal of Econometrics, 87, 115-143.

Borensztein, E., De Gregorio, J.and Lee, J-W., (1998) "How Does Foreign Direct Investment Affect Economic Growth?” Journal of International Economics, 45, 115-135.

Bortolotti, B., de Jong, F., Nicodano, G., and Schindele, I. (2007) "Privatization and stock market liquidity", Journal of Banking and Finance, 31, 297-316.

Bortolotti, B., Fantini , M. and Siniscalco, D. (2003) "Privatization around the world: Evidence from panel data", Journal of Public Economics, 88, 305-332.

Boubakri, N, Cosset, J-C., and Guedhami, O. (2005a) "Postprivatization corporate governance: The role of ownership structure and investor protection” Journal of Financial Economics, 76, 369-399.

Boubakri, N, Cosset, J-C., and Guedhami, O. (2005b) "Liberalization, corporate governance and the performance of privatized firms in developing countries" Journal of Corporate Finance, 11, 767-790.

Boubakri, N., Cosset, J-C., and Smaoui, H. (2009) "Does Privatization Foster Changes in the Quality of Legal Institutions ?” Journal of Financial Research, 32, 169-197.

Boutchkova, M. K. and Megginson, W. L. (2000) "Privatization and the Rise of Global Capital Markets", Financial Management, 28, 31-76.

Bowsher, C. G. (2002) “On testing overidentifying restrictions in dynamic panel data models”, Economic Letters, 77, 211-220. 
Choe, H., Kho, B-C., and Stulz, R. (1999) "Do Foreign Investors Destabilize Stock Markets? The Korean Experience in 1997”, Journal of Financial Economics, 54, 227-264.

Chong, A., and Gradstein, M. (2007) "Inequality and Institutions", The review of Economics and Statistics, 89, 454-465.

Cragg, J., G., and Donald, S., G. (1993) “Testing Identifiability and Specification in Instrumental Variable Models", Econometric Theory, 9, 222-240.

Djankov, S., La Porta, R., Lopez-de-Silanes, F. and Shleifer, A. (2008) "The Law and Economics of Selfdealing", Journal of Financial Economics, 88, 430-465.

Daude, C., and Fratzscher, M. (2008) “The Pecking-Order of Cross-Border Investment”, Journal of International Economics, 74, 94-119.

D’Souza, J., and Megginson, W. L. (1999) “The Financial and Operating Performance of Privatized Firms during the 1990", Journal of Finance 54, 1397-1438.

Eichengreen, B., and Leblang, D. (2008) "Democracy and Globalization”, Economics and Politics,20, 289-334.

French, K. R., and Poterba, J. P. (1991) “Investor Diversification and International Equity Markets”, The American Economic Review, 81, 222-226.

Eiteman, D., Stonehill, A. and Moffett, M. (2007) "Multinational Business Finance", $11^{\text {th }}$ Edition, The AddisonWesley Series in Finance.

Froot, K. A., O'Connell, P. G. J., and Seasholes, M. S. (2001) “The Portfolio Flows of International Investors”, Journal of Financial Economics, 59, 151-193.

Harper, J. T., (2002) “The Performance of Privatized Banks in the Czech Republic", Journal of Banking and Finance, 26, 621-649.

Henisz, W. J., (2000) “The Institutional Environment for Economic Growth”, Economics and Politics, 12, 1-31.

Holtz-Eakin, D., Whitney, N., and Rosen, H. (1988) "Estimating Vector Autoregressions with Panel Data", Econometrica, 56, 1371-1395.

Karolyi, G. A. and Stulz, R. M. (2003) “Are Financial Assets Priced Locally or Globally?” The Handbook of the Economics of Finance, Constantinides, G., Harris, M. and Stulz, R. M. (eds.), North Holland.

Kaufmann, D., and Siegelbaum, P. (1997) "Privatization and Corruption in Transition Economies “, Journal of International Affairs, 50, 419-458.

Khawar, M. (2005) "Foreign Direct Investment and Economic Growth: A Cross-Country Analysis", Global Economy Journal, 5, 1-13.

La Porta, R., Lopez-de-Silanes, F., Shleifer, A. and Vishny, R. W (1998) "Law and Finance”, Journal of Political Economy, 106, 1113-1150.

Li, Q. and Resnick, A (2003) "Reversal of Fortunes: Democratic Institutions and Foreign Direct Investment Inflows to Developing Countries", International Organization, 57, 175-211. 
Megginson, W. L., and Netter, J. M. (2001) "From state to market: A survey of empirical studies on privatization", Journal of Economic Literature, 39, 321-389.

Megginson, W. L., Nash, R., Netter, J. N., and Poulsen, A. B. (2004) "The choice of private versus public capital markets: Evidence from privatizations", Journal of Finance, 59, 2835-2870.

Mishkin, F. S., (2009) “Globalization and Financial Development”, Journal of Development Economics, 89, 164169.

Noorbakhsh, F., Paloni , A. and Youssef, A. (2001) "Human capital and FDI inflows to Developing Countries: New Empirical Evidence”, World Development, 29, 1593-1610.

Perotti, E. (1995) “Credible Privatization”, American Economic Review, 85, 847-859.

Perotti, E. and van Oijen, P. (2001) "Privatization, Market Development, and Political Risk in Emerging Economies", Journal of International Money and Finance, 20, 43-69.

Portes, R. and Rey, H. (2005) "The Determinants of Cross-Border Equity Flows", Journal of International Economics, 65, 269-296.

Ramamurti, R. (1992), “Why are Developing Countries Privatizing?” Journal of International Business Studies, 23, 225-249.

Roodman, D. (2007) "A Short Note on the Theme of Too Many Instruments", Center for Global Development, Working paper number 125, 1-32.

Schneider, F. and Frey, B. (1985) "Economic and Political Determinants of Foreign Direct Investment", World Development, 13, 161-175.

Shleifer, A. (1998) "State versus Private Ownership", Journal of Economic Perspectives, 12, 133-150

Stock, J., H., Wright, J., H. and Yogo, M. (2002) "State versus Private Ownership", Journal of Business and Economic Statistics, 20, 518-529

Stock, J., H. and Yogo, M. (2005) "Testing for weak instruments in linear IV regressions", in Stock, J.H., Andrews, D.W.K., (Eds.), Identification and Inference for Econometric Models: AFestschrift in Honor of Thomas Rothenberg, Cambridge University Press, Cambridge, Ch. 5, 80-108

Tsai, P.-L. (1994) “Determinants of Foreign Direct Investment and its Impact on Economic Growth", Journal of Economic Development, 19, 137-163.

White, H. (1980) “A Heteroskedasticity-Consistent Covariance Matrix Estimator and a Direct Test for Heteroskedasticity", Econometrica, 48, 817-838.

Windmeijer, F. (2005) “A finite sample correction for the variance of linear efficient two-step GMM estimators", Journal of Econometrics, 126, 25-51.

World Bank, World Development Report 2002: Building Institutions for Markets.

World Bank, World Development Report 2003: Sustainable Development in a Dynamic World.

World Bank, World Development Report 2006: Equity and Development. 
World Bank, Global Development Finance 2008: The Role of International Banking,

World Bank, Global Development Finance 2010: External Debt of Developing Countries. 